\title{
НАТУРНІ ДОСЛІДЖЕННЯ ПАРАМЕТРІВ МІКРОКЛІМАТУ КУПОЛЬНОЇ ОРАНЖЕРЕЇ НБС ІМ. М.М. ГРИШКА НАН УКРАЇНИ
}

\author{
О.В. Хіменко, канд. техн. наук, О.О. Хіменко
}

Інститут відновлюваної енергетики НАН України,

02094, вул. Гната Хоткевича, 20А, м. Київ, Україна.

Дана робота присвячена комплексному дослідженню мікрокліматичних параметрів купольної оранжереї "Тропічний ліс" НБС ім. М.М. Гришка з метою організації ефективної природної вентиляції (аераиії) оранжереї у теплий період року. Дослідження проводились у декілька етапів. На першому етапі були виконані виміри температури і вологості повітря в купольній оранжереї. На другому етапі були проведені натурні дослідження температури та швидкості руху повітря у повітрозабірній шахті купольної оранжереї у літній період. Отримані дані про температуру, вологість, швидкість повітря у купольній оранжереї впродовж року, а також у повітрозабірній шахті купольної оранжереї у літній період року. Виконано аналіз отриманих даних та динаміки зміни цих параметрів, результати якого представлені в графічній формі. На основі отриманих даних натурних досліджень була розрахована аерація купольної оранжереї НБС ім. М.М. Гришка для трьох випадків: 1. Під дією різниці тисків зовнішнього і внутрішнього повітря; 2. Під дією вітру (вітрова аерація); 3. При одночасній дії різниці тисків зовнішнього і внутрішнього повітря та дії вітру. Отримані площуі припливних та витяжних вентиляиійних отворів, швидкість та витрата повітря через них. Запропонована схема розміщення вентиляційних отворів для забезпечення ефективної аерачії приміщення купольної оранжереї НБС ім. М.М. Гришка. Організація ефективної аераиії купольної оранжереї дасть змогу створити більш сприятливі мікрокліматичні умови для тропічних рослин у теплий період року. Бібл. 5, табл. 10, рис. 4.

Ключові слова: натурні дослідження, температура повітря, вологість, ивидкість та витрата повітря, вентиляційні отвори, аерація

\section{NATURAL RESEARCH OF PARAMETERS MICROCLIMATE DOME GREENHOUSE NBG NAME'S M.M. GRISHKO NAS OF UKRAINE}

\author{
A. Khimenko, candidate of technical science, H. Khimenko \\ Institute of Renewable Energy of the National Academy of Sciences of Ukraine, \\ 02094, 20A Hnata Khotkevycha St., Kyiv, Ukraine.
}

This work is devoted to a comprehensive research of the microclimatic parameters of the dome greenhouse "Rainforest" NBG name's M. M. Grishko in order to organize effective natural ventilation (aeration) of the greenhouse during the warm season of the year. The research was carried out in several stages. At the first stage, measurements of temperature and humidity in the dome greenhouse were performed. At the second stage, natural researches of temperature and air velocity in the air intake mine of the dome greenhouse in the summer period were carried out. The data were obtained on the temperature, humidity, air velocity in the dome greenhouse during the year, as well as in the air intake shaft of the dome greenhouse in the summer period of the year. The analysis of the obtained data and the dynamics of changes in these parameters is performed. The results of the analysis are presented in graphical form. On the basis of the obtained data of natural researches, aeration of the dome greenhouse of NBG name's M. M. Grishko was calculated for three cases: 1. Under the influence of the pressure difference between the external and the internal air; 2 . Under the influence of wind (wind aeration); 3. With the simultaneous influence of the pressure difference between the external air and the internal air and the influence of the wind. The areas of supply and exhaust ventilation openings, speed and air flow through them were obtained. The scheme of placement of ventilation openings is proposed to provide efficient aeration of the dome greenhouse of the NBG name's M. M. Grishko. The organization of effective aeration of the dome greenhouse will allow creating more favorable microclimatic conditions for tropical plants in the warm season. Ref.5, tabl. 10, fig. 4.

Keywords: natural researches, air temperature, humidity, air velocity and flow, ventilation openings, aeration

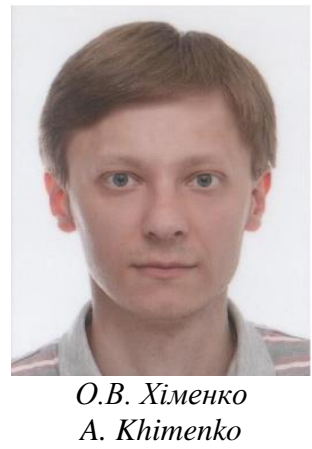

Відомості про автора: науковий співробітник відділу геотермальної енергетики Інституту відновлюваної енергетики НАН України, кандидат технічних наук.

Освіта: Харківська національна академія міського господарства.

Наукова сфера: високо- та низькотемпературне акумулювання теплоти, використання теплоти довкілля.

Публікації: 24.

ORCID: 0000-0003-2612-969X

Контакти: тел./факс +38 (044) 206-28-09

e-mail: avmkh87@gmail.com
Author information: researcher of geothermal energy department, Institute of renewable energy of National Academy of Sciences of Ukraine, candidate of technical science.

Education: Kharkiv national academy of urban economy.

Research area: high and low temperature heat storage, use of environmental heat.

Publications: 24.

ORCID: 0000-0003-2612-969X

Contacts: phone/fax +38 (044) 206-28-09

e-mail: avmkh87@gmail.com

(C) О.В. Хіменко, О.О. Хіменко, 2019 


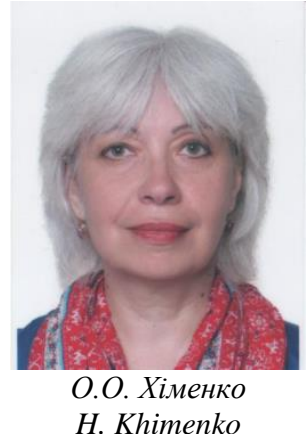

Відомості про автора: провідний інженер відділу науково-технічної інформації Інституту відновлюваної енергетики НАН України.

Освіта: Макіївський інженерно-будівельний інститут, Українська інженерно-педагогічна академія (м. Харків).

Наукова сфера: використання теплоти довкілля.

Публікації: 15 .

ORCID: 0000-0002-8422-2078

Контакти: тел./факс +38 (044) 206-28-09, e-mail: noo.sk.ive@gmail.com
Author information: leading engineer of scientific and technical information department of the Institute of renewable energy of the National Academy of Sciences of Ukraine.

Education: Makeyevsky Engineering and Building Institute, Ukrainian engineering and pedagogical Academy (Kharkiv).

Research area: use of environmental heat.

Publications: 15.

ORCID: 0000-0002-8422-2078

Contacts: phone/fax +38 (044) 206-28-09

e-mail: noo.sk.ive@gmail.com
Перелік використаних позначень та скорочень

НБС ім. - Національний ботанічний сад ім. М.М.

M.M. Гришка Національної академії наук УкраїГришка ни;

$\mathrm{HAH}$

України

$\varphi-$ відносна вологість повітря, \%;

$V_{\text {ср.пов. }} \quad$ - середня швидкість повітря у повітрозабірній шахті, виміряна в процесі проведення натурних досліджень, м/с;

$T_{\text {пов.зов. }} \quad-$ температура зовнішнього повітря, ${ }^{\circ} \mathrm{C}$;

$T_{\text {пов.вн. }} \quad$ - температура внутрішнього повітря у повітрозабірній шахті купольної оранжереї, виміряна в процесі проведення натурних досліджень, ${ }^{\circ} \mathrm{C}$;

$T_{\text {вит }}-$ температура витяжного повітря на висоті верхнього вентиляційного отвору купольної оранжереї, ${ }^{\circ} \mathrm{C}$;

$T_{\mathrm{cp}} \quad-$ середня температура повітря у купольній оранжереї, ${ }^{\circ} \mathrm{C}$;

$\rho_{\text {зов }}$ - щільність зовнішнього повітря при $30{ }^{\circ} \mathrm{C}$, кг/ $\mathrm{M}^{3}$

$\rho_{\mathrm{cp}} \quad-$ щільність повітря при середній температурі повітря купольної оранжереї, кг/м³

$\rho_{\text {вит }}-$ щільність повітря при температурі витяжного повітря на висоті верхнього вентиляційного отвору, кг/ $\mathrm{m}^{3}$;

$p_{\text {над }} \quad-$ надлишковий тиск на рівні підлоги купольної оранжереї, Па;

$h_{1,3} \quad$ - висота від рівня підлоги до центру припливних вентиляційних отворів купольної оранжереї, м;

$h_{2,4}-$ висота від рівня підлоги до центру витяжних вентиляційних отворів купольної оранжереї, м;

$p_{1-4}$ гр - гравітаційний тиск в площині (по центру) припливних та витяжних вентиляційних отворів, Па;

$V_{1-4}$ гр - розрахункова швидкість повітря через припливні та витяжні вентиляційні отвори під дією гравітаційного тиску, м/с;

$F_{1,3}$ пр - площа припливних вентиляційних отворів купольної оранжереї, м²;

$F_{2,4 \text { в }}$ - площа витяжних вентиляційних отворів купольної оранжереї, м $^{2}$;

Вступ. Аерація - це природний організований повітрообмін у приміщеннях, який відбувається через вентиляційні отвори у зовнішніх огороджувальних конструкціях будівель під дією вітру або під спільною дією вітру та різниці тисків зовнішнього та внутрішнього повітря (граві-
M - коефіцієнт витрати, який враховує місцевий спротив при вході та виході повітря через вентиляційні отвори;

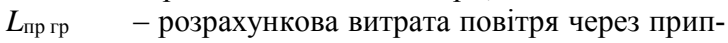
ливні вентиляційні отвори купольної оранжереї під дією гравітаційного тиску, $\mathrm{m}^{3} / \mathrm{c}$;

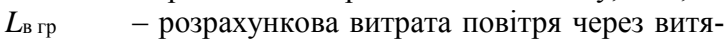
жні вентиляційні отвори купольної оранжереї під дією гравітаційного тиску, $\mathrm{m}^{3} / \mathrm{c}$;

$L_{\mathrm{cp}} \quad$ - середня розрахункова витрата повітря, $\mathrm{M}^{3} / \mathrm{c}$;

$p_{\text {д }}-$ динамічний тиск вітру, Па;

$V_{\text {в }} \quad$ - середня швидкість вітру, м/с;

$\Delta p_{1-4}$ д - розрахунковий перепад тиску у площині вентиляційних отворів під дією вітру, Па;

$K_{1,2}-$ аеродинамічний коефіцієнт 3 навітряної сторони будівлі купольної оранжереї;

$K_{3,4}-$ аеродинамічний коефіцієнт 3 підвітряної сторони будівлі купольної оранжереї;

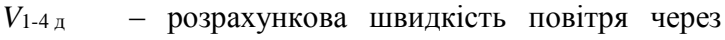
припливні та витяжні вентиляційні отвори під дією вітру, м/с;

$L_{\text {пр д }} \quad$ - розрахункова витрата повітря через припливні вентиляційні отвори купольної оранжереї під дією вітру, м ${ }^{3} / \mathrm{c}$;

$L_{\text {в д }}-$ розрахункова витрата повітря через витяжні вентиляційні отвори купольної оранжереї під дією вітру, $\mathrm{m}^{3} / \mathrm{c}$;

$p_{1-4}$ од - значення тиску в площині припливних та витяжних вентиляційних отворів при одночасній дії гравітаційного тиску та дії вітру, Па;

$V_{1-4}$ од - розрахункова швидкість повітря через припливні та витяжні вентиляційні отвори при одночасній дії гравітаційного тиску та дії вітру, м/с;

$L_{\text {пр од }} \quad$ - розрахункова витрата повітря через припливні вентиляційні отвори купольної оранжереї при одночасній дії гравітаційного тиску та дії вітру, $\mathrm{m}^{3} / \mathrm{c}$;

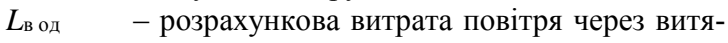
жні вентиляційні отвори купольної оранжереї при одночасній дії гравітаційного тиску та дії вітру, $\mathrm{m}^{3} / \mathrm{c}$.

таційний тиск). Такий повітрообмін називається організованим тому, що він дозволяє здійснити заздалегідь задане провітрювання і регулювати його відповідно до внутрішніх та зовнішніх умов. При цьому великі об'єми зовнішнього повітря надходять та видаляються 3 приміщення при не- 
значному тиску (до 10 Па). В той же час при роботі механічної вентиляції достатньо невеликі об'єми повітря переміщуються при значно більших значеннях тиску (400-600 Па) [1].

Гравітаційний тиск, який утворюється за рахунок різниці температур зовнішнього та внутрішнього повітря, може регулюватися різним ступенем відкриття вентиляційних отворів. Перевищення зовнішнього тиску над внутрішнім забезпечує надходження повітря до приміщення через вентиляційні отвори, а перевищення внутрішнього тиску над зовнішнім забезпечує видалення його з приміщення [2].

Постановка завдання. Для організації ефективної аерації купольної оранжереї "Тропічний ліс" необхідно здійснити натурні дослідження мікрокліматичних параметрів в приміщенні купольної оранжереї впродовж теплого періоду року, а саме: 1. Виміряти температуру та вологість повітря в приміщенні купольній оранжереї, а також у повітрозабірній шахті в підвальному приміщенні оранжереї; 2. Виміряти швидкість руху повітря у повітрозабірній шахті купольної оранжереї. На наступному етапі необхідно проаналізувати динаміку зміни температури та швидкості повітря у купольній оранжереї впродовж періоду спостережень. На основі отриманих результатів натурних досліджень розрахувати аерацію купольної оранжереї: 1. Під дією різниці тисків зовнішнього і внутрішнього повітря; 2. Під дією віт- ру; 3. При одночасній дії різниці тисків зовнішнього і внутрішнього повітря та дії вітру.

Результати дослідження. На першому етапі проведені виміри температури повітря та вологості у приміщенні купольної оранжереї НБС ім. M.M. Гришка та у повітрозабірній шахті в підвальному приміщенні оранжереї. Були встановлені термометри ТC-7-M1 у декількох точках купольної оранжереї: у центрі на висоті 0,2 м (T1) від рівня підлоги та два термометри по периметру оранжереї; на позначці 1,0 м (T2) та 8,0 м (T3); у повітрозабірній шахті в підвальному приміщенні купольної оранжереї (T4), а також гігрометр BIT-2 для вимірювання вологості на висоті 1,0 м у повітрозабірній шахті і у приміщенні купольної оранжереї. Фіксувалось значення температури внутрішнього повітря у купольній оранжереї протягом 8 місяців (з березня по жовтень). Вимірювання відносної вологості у приміщенні купольної оранжереї та у повітрозабірній шахті проводились впродовж 4 місяців (з липня по жовтень). За період спостережень значення відносної вологості $\varphi$ не перевищували 95\% та не опускалось нижче $90 \%$. Важливо відмітити, що на висоті 8 м у купольній оранжереї в літні місяці фіксувалась достатньо висока температура повітря $\left(40-43^{\circ} \mathrm{C}\right)$, яка чинила негативний вплив на тропічну рослинність оранжереї особливо на рослини висотою більше 5 м. Результати вимірів температури повітря у купольній оранжереї представлені на рис. 1 [3].

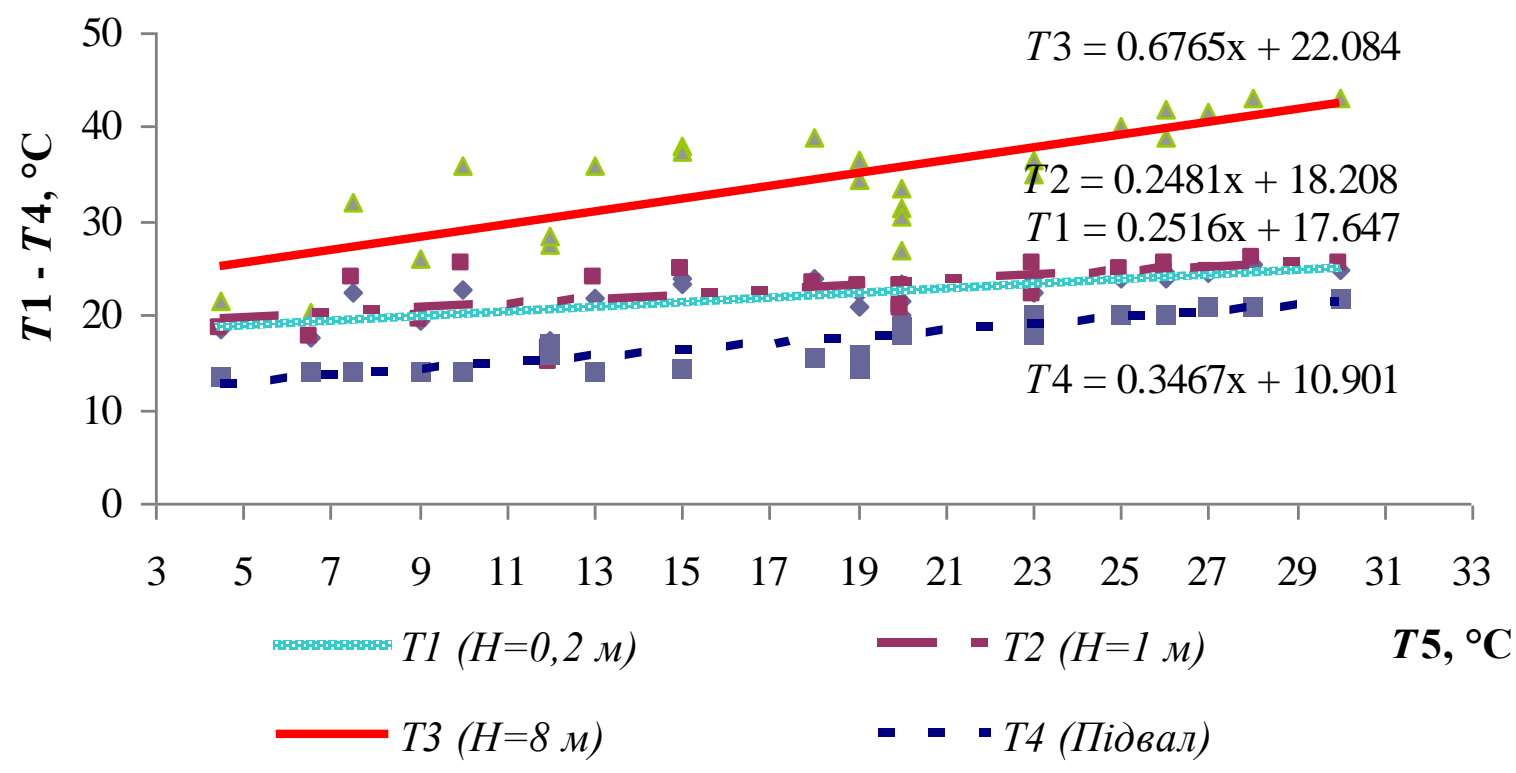

Рис. 1. Зміна температури внутрішнього повітря у купольній оранжереї в залежності від зовнішньої температури повітря.

Fig. 1. Changing the temperature of the internal air in the dome greenhouse depending on the external temperature of the air. 
На другому етапі було проведені виміри швидкості руху повітря у повітрозабірній шахті купольної оранжереї у літній період з метою організації ефективної природної вентиляції купольної оранжереї. Виміри проводились у кінцевій частині тунелю повітрозабірної шахти, де вона під'єднується до повітророзподільни- ків. Проведено низку вимірів за допомогою крильчатого анемометру АCO-3 у період 3 червня по серпень. Результати вимірів середньої швидкості повітря в залежності від температури зовнішнього повітря $T_{\text {пов зов }}$ та внутрішнього

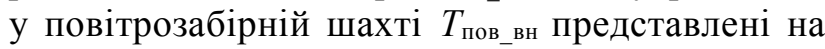
рис. 2 [3].

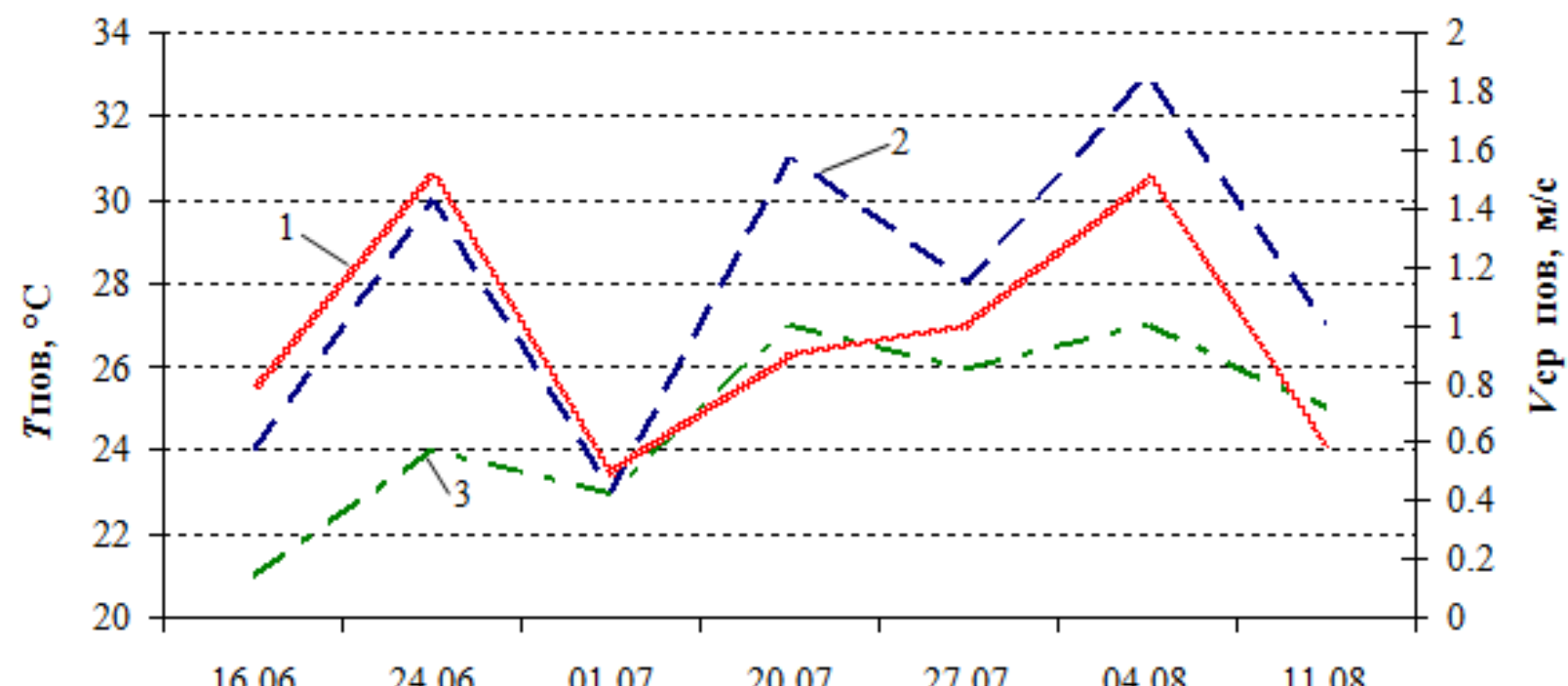

Дата

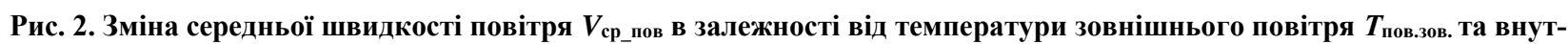
рішнього $\boldsymbol{T}_{\text {пов.вн.: }} 1$ - температура внутрішнього $T_{\text {пов.вн., }}{ }^{\circ} \mathrm{C} ; 2$ - температура зовнішнього повітря $T_{\text {пов.зов., }}{ }^{\circ} \mathrm{C} ; 3$ - середня швидкість повітря у повітрозабірній шахті $V_{\text {ср.пов., }}$ /с.

Fig. 2. Change of average air velocity $\boldsymbol{V}_{\text {av_air }}$ depending on the temperature of external air $\boldsymbol{T}_{\text {air.ex. }}$ and internal $\boldsymbol{T}_{\text {air.in.: }} 1-$ the temperature of internal air $T_{\text {air.in. }}{ }^{\circ} \mathrm{C} ; 2$ - the temperature of external air $T_{\text {air.ex. }},{ }^{\circ} \mathrm{C} ; 3$-average air velocity in the air intake mine Vav.air, $m / s$

Як видно з рис. 2, середня швидкість повітря

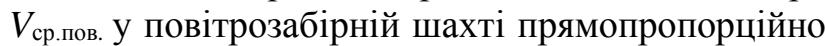
залежить від різниці температури зовнішнього та внутрішнього повітря. Швидкість вимірюваного повітряного потоку у повітрозабірній шахті не стала. У зв'язку з мінливістю швидкості вітру спостерігалися істотні коливання вимірюваної величини. Часом через малу різницю температур зовнішнього і внутрішнього повітря, швидкість повітряного потоку у повітрозабірній шахті падала до нуля. Зважаючи на це, ефективність роботи системи природної вентиляції буде напряму залежати від погодних умов та швидкості вітру. Таким чином, система природної вентиляції купольної оранжереї "Тропічний ліс" НБС ім. М.М. Гришка 3 використанням повітрозабірної шахти та мережі повітророзподільників є малоефективною для організації необхідного повітрообміну в приміщенні купольної оранжереї у літній період року.

На третьому етапі був виконаний розрахунок аерації купольної оранжереї для трьох випадків: 1. Під дією гравітаційного тиску; 2. Під дією вітру; 3. При одночасній дії різниці тисків зовнішнього і внутрішнього повітря та дії вітру.

Для розрахунку аерації купольної оранжереї під дією гравітаційного тиску задаємо значення температури робочої зони, температури витяжного повітря, температури зовнішнього повітря, щільності повітря при заданих температурах [4] та висоту від рівня підлоги до центрів припливних та витяжних отворів (табл. 1).

Таблиця 1. Вихідні дані для розрахунку аерації купольної оранжереї НБС ім. М.М. Гришка.

Table 1. Initial data for calculation of aeration of dome greenhouse of NBG name's M. M. Grishko.

\begin{tabular}{|c|c|c|c|c|c|c|c|c|c|c|}
\hline$T_{\text {р.з. }},{ }^{\circ} \mathrm{C}$ & $T_{\text {вит }},{ }^{\circ} \mathrm{C}$ & $T_{\text {ср }},{ }^{\circ} \mathrm{C}$ & $T_{\text {3ов } п \text { пов }}{ }^{\circ} \mathrm{C}$ & $\rho_{\text {ср, кг } /{ }^{3}}$ & $\rho_{\text {зов, кг } / \mathrm{M}^{3}}$ & $\Delta \rho$, кг $/{ }^{3}$ & $h_{1}, \mathrm{M}$ & $h_{2}, \mathrm{M}$ & $h_{3}, \mathrm{M}$ & $h_{4}, \mathrm{M}$ \\
\hline 25 & 43 & 34 & 30 & 1,15 & 1,165 & 0,015 & 3 & 20 & 3 & 20 \\
\hline
\end{tabular}


Температура зовнішнього повітря $T_{\text {зов.пов. та }}$

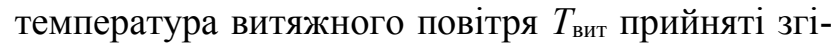
дно 3 максимальними значеннями виміряних температур $T 5$ та $T 3$ в літні місяці в процесі проведення натурних спостережень (див. рис. 1).

Середня температура в купольній оранжереї $T_{\text {ср визначається за формулою }}$

$$
T_{\mathrm{cp}}=\frac{\left(T_{\mathrm{p} .3 .}+T_{\text {вит }}\right)}{2},
$$

де $T_{\text {р.з. }}$ - температура робочої зони, ${ }^{\circ} \mathrm{C} ; T_{\text {вит }}-$ температура витяжного повітря на висоті верхнього вентиляційного отвору, ${ }^{\circ} \mathrm{C}$.

Визначаємо $\Delta \rho, \kappa г / \mathrm{m}^{3}$, як різницю щільності

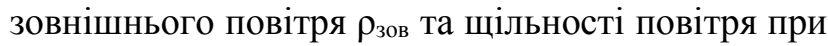
середній температурі повітря в купольній оранжереї $\rho_{\mathrm{cp}}$

$$
\Delta \rho=\rho_{\text {зов }}-\rho_{\mathrm{cp}} .
$$

Розраховуємо аерацію методом надлишкових тисків [1]. Приймаємо надлишковий тиск на рівні підлоги купольної оранжереї $p_{\text {над }}=-1$ Па.

Визначаємо надлишковий (гравітаційний) тиск в площині припливних та витяжних вентиляційних отворів за наступними формулами [1]

$$
\begin{array}{ll}
p_{1 \text { гр }}=p_{\text {над }}+\Delta \rho g h_{1} ; & p_{\text {Згр }}=p_{\text {над }}+\Delta \rho g h_{3} ; \\
p_{2 \text { гр }}=p_{\text {над }}+\Delta \rho g h_{2} ; & p_{\text {ггр }}=p_{\text {над }}+\Delta \rho g h_{4},
\end{array}
$$

де $h_{1,3}$ - висота від рівня підлоги до центру припливних вентиляційних отворів купольної оранжереї, м; $h_{2,4}$ - висота від рівня підлоги до центру витяжних вентиляційних отворів купольної оранжереї, м.

Результати розрахунку гравітаційного тиску

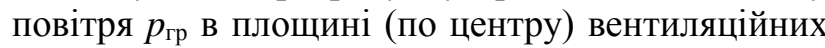
отворів приведені у табл. 2.

Таблиця 2. Результати розрахунку гравітаційного тиску повітря в площині вентиляційних отворів купольної

\begin{tabular}{|c|c|c|c|}
\hline$p_{1 \text { гр, }}$, Па & $p_{2 \text { гр }}$, Па & $p_{3 \text { гр }}$, Па & $p_{4 \text { гр }}$, Па \\
\hline 1,44 & 1,94 & 1,44 & 1,94 \\
\hline
\end{tabular}
оранжереї.

Table 2. Results calculation of gravitational air pressure in the plane of the ventilation openings of the dome greenhouse.

Визначаємо швидкість повітря $V_{1-4}$ м/с через припливні та витяжні вентиляційні отвори під дією гравітаційного тиску за наступними формулами [1]

$$
\begin{array}{ll}
V_{1}=\sqrt{\frac{2 p_{1}}{\rho_{\text {зов }}}} ; & V_{3}=\sqrt{\frac{2 p_{3}}{\rho_{\text {зов }}}} ; \\
V_{2}=\sqrt{\frac{2 p_{2}}{\rho_{\mathrm{cp}}}} ; & V_{4}=\sqrt{\frac{2 p_{4}}{\rho_{\mathrm{cp}}}} .
\end{array}
$$

Результати розрахунку швидкості повітря через вентиляційні отвори приведені у табл. 3 .

Таблиця 3. Результати розрахунку швидкості повітря

$V_{1-4}$ гр через вентиляційні отвори купольної оранжереї під дісю гравітаційного тиску.

Table 3. Results calculation of air velocity $V_{1-4}$ gr through the ventilation openings of the dome greenhouse under the influence of gravitational pressure.

\begin{tabular}{|c|c|c|c|}
\hline$V_{1 \text { гр }, \mathrm{M} / \mathrm{c}}$ & $V_{2 \text { гр, }, \mathrm{M} / \mathrm{c}}$ & $V_{3 \text { гр }, \mathrm{M} / \mathrm{c}}$ & $V_{4 \text { гр }, \mathrm{M} / \mathrm{c}}$ \\
\hline 1,44 & 1,94 & 1,44 & 1,94 \\
\hline
\end{tabular}

Підбираємо площі припливних та витяжних вентиляційних отворів у співвідношенні $F_{\text {пр }} / F_{\text {в }}=$ 1,25 (див. табл. 4).

Таблиця 4. Площі припливних та витяжних вентиляційних отворів для забезпечення аерації купольної оранжереї НБС ім. М.М. Гришка.

Table 4. Areas of supply and exhaust ventilation openings to provide aeration of the dome greenhouse NBG name's M.M. Grishko.

\begin{tabular}{|c|c|c|c|}
\hline$F_{3 \text { пр }}, \mathrm{M}^{2}$ & $F_{1 \text { пр }}, \mathrm{M}^{2}$ & $F_{2 \text { в }}, \mathrm{M}^{2}$ & $F_{4 \_\mathrm{B}}, \mathrm{M}^{2}$ \\
\hline 3,2 & 3,2 & 2,6 & 2,6 \\
\hline
\end{tabular}

Визначаємо баланс витрати припливного $L_{\text {пр гр }}$

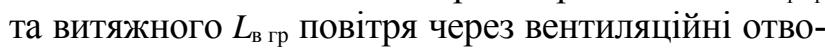
ри під дією гравітаційного тиску по формулі [1]

$$
\begin{aligned}
& \mu \cdot\left(V_{1 г \mathrm{p}} \cdot F_{1 \text { пр }}+V_{3 \text { гр }} \cdot F_{3 \text { пр }}\right) \cdot \rho_{\text {зов }}= \\
& =\mu \cdot\left(V_{2 \text { гр }} \cdot F_{2 \mathrm{~B}}+V_{4 \text { гр }} \cdot F_{4 \mathrm{~B}}\right) \cdot \rho_{\text {вит }}
\end{aligned}
$$

Приймаємо значення коефіцієнта витрати $\mu$, який враховує місцевий спротив при вході та виході повітря через вентиляційні отвори, $0,65[1]$.

Результати розрахунку витрати припливного та витяжного повітря через вентиляційні отвори приведені у табл. 5.

Таблиця 5. Результати розрахунку витрати повітря через припливні та витяжні вентиляційні отвори купольної оранжереї НБС ім. М.М. Гришка під дією гравітаційного тиску.

Table 5. The results calculation of air flow through the supply and exhaust ventilation openings of the dome greenhouse NBG name's M. M. Grishko under the influence of gravitational pressure.

\begin{tabular}{|c|c|c|}
\hline$L_{\text {пр гр }}, \mathrm{M}^{3} / \mathrm{c}$ & $L_{\mathrm{B} \mathrm{гр}}, \mathrm{M}^{3} / \mathrm{c}$ & $L_{\text {ср гр }, \mathrm{M}^{3} / \mathrm{c}}$ \\
\hline 6,54 & 6,21 & 6,38 \\
\hline
\end{tabular}

Нев'язка по витраті припливного та витяжного повітря під дією гравітаційного тиску складає $5,31 \%$, що є в межах максимального значення нев'язки - $10 \%$ [1]. 


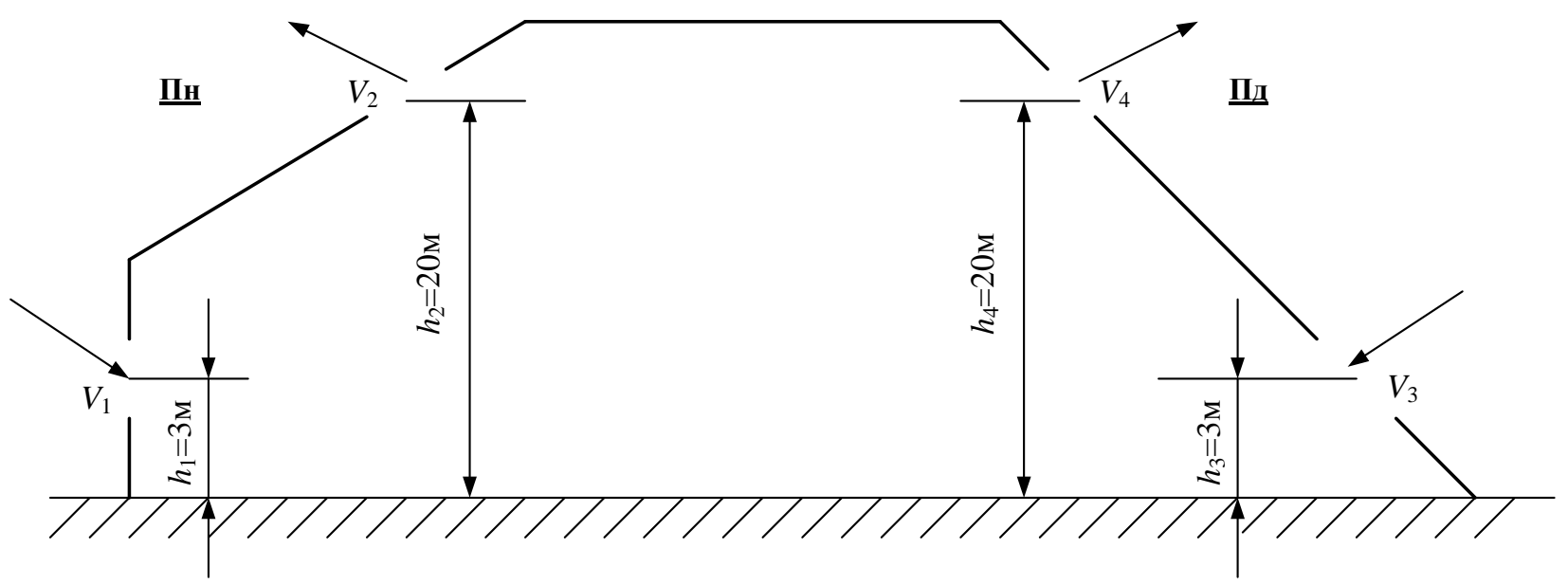

Рис. 3. Схема розміщення припливних та витяжних отворів та напрям руху повітря через вентиляційні отвори купольної оранжереї НБС ім. М.М. Гришка під дісю гравітаційного тиску.

Fig. 3. The scheme placement of supply and exhaust openings and the direction of air flow through the ventilation openings of the dome greenhouse NBG name's M. M. Grishko under the influence of gravitational pressure.

Розрахунок під дією вітру

Для розрахунку аерації під дією вітри визна-

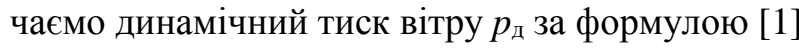

$$
p_{\text {д }}=\frac{V_{\mathrm{B}}^{2} \rho_{\text {зов }}}{2} .
$$

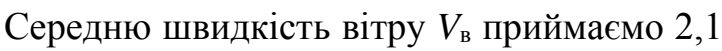
м/с для літніх місяців у м. Києві [5].

Приймаємо середнє значення аеродинамік- ного коефіцієнту $K_{1,2} 3$ навітряної сторони будівлі купольної оранжереї $+0,8$, а 3 підвітряної сторони приймаємо $K_{3,4}=-0,6$ [2]. Таким чином, при вітровій аерації повітря до будівлі купольної оранжереї буде надходити через вентиляційні отвори на висоті 3 м та 20 м 3 північної сторони будівлі, а видалення повітря буде відбуватися 3 аналогічних вентиляційних отворів, що розташовані на південній стороні купольної оранжереї (див. рис. 4).

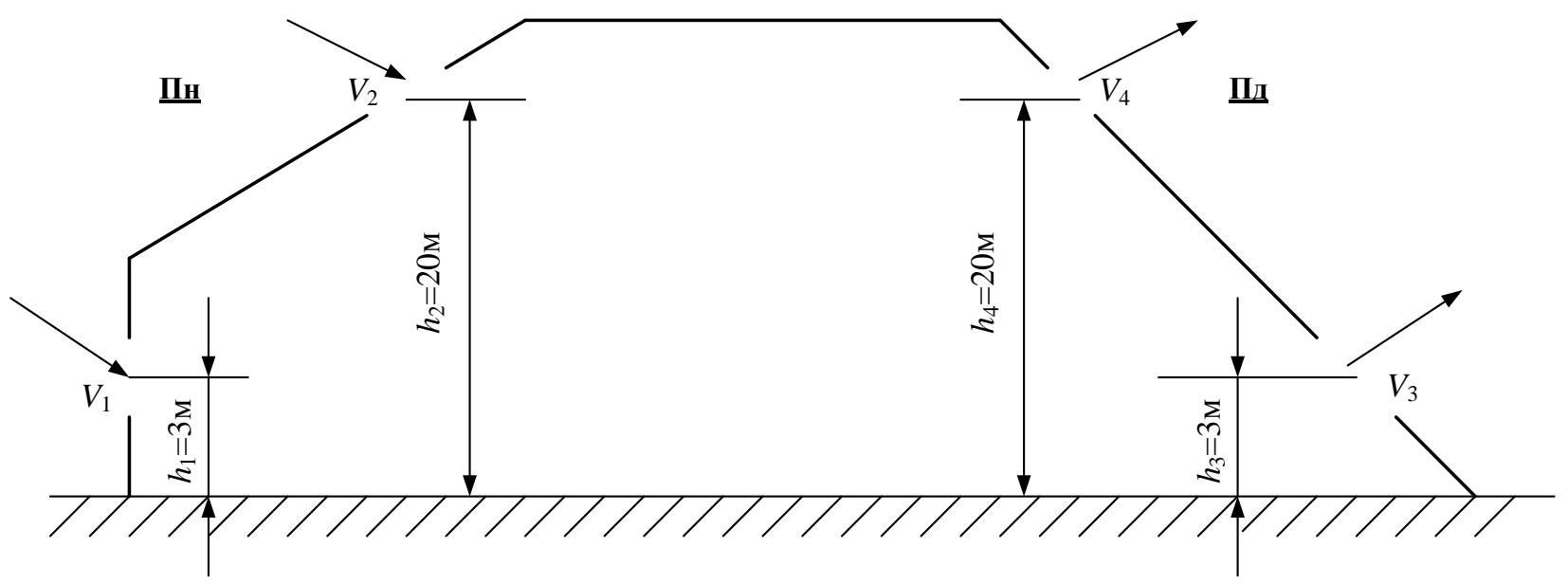

Рис. 4. Схема розміщення припливних та витяжних отворів та напрям руху повітря через вентиляційні отвори купольної оранжереї НБС ім. М.М. Гришка під дісю вітру.

Fig. 4. The scheme placement of supply and exhaust openings and the direction of air flow through the ventilation openings of the dome greenhouse of NBG name's M. M. Grishko under the influence of wind. 
Визначаємо тиск в площині вентиляційних отворів як добуток динамічного тиску повітря $p_{\text {д }}$ та аеродинамічного коефіцієнту $K$. Результати розрахунків приведені у табл. 6.

Таблиця 6. Результати розрахунку тиску в площині вентиляційних отворів під дією вітру

Table 6. Results calculation of pressure in the plane of ventilation openings under the influence of wind

\begin{tabular}{|c|c|}
\hline$K_{1,2} p_{\text {д }}, \Pi \mathrm{a}$ & $K_{3,4} p_{\text {д }}, \Pi \mathrm{a}$ \\
\hline 2,06 & $-1,54$ \\
\hline
\end{tabular}

Приймаємо надлишковий тиск на рівні підлоги купольної оранжереї $p_{\text {над }}=-1$ Па та визначаємо розрахункові перепади тиску у площині вентиляційних отворів під дією вітру за формулами [1]

$$
\begin{aligned}
& \Delta p_{1,2 \text { д }}=K_{1,2} p_{\text {д }}-p_{\text {над }} ; \\
& \Delta p_{3,4 \text { д }}=-K_{3,4} p_{\text {д }}-p_{\text {над }} .
\end{aligned}
$$

Результати розрахунків перепадів тиску у площі вентиляційних отворів під дією вітру приведені у табл. 7.

Таблиця 7. Результати розрахунку перепаду тиску в площині вентиляційних отворів під дісю вітру.

Table 7. Results calculation of pressure drop in the plane of ventilation openings under the influence of wind.

\begin{tabular}{|c|c|}
\hline$\Delta p_{1,2 \text { д }}$, Па & $\Delta p_{3,4 \text { д, Па }}$ \\
\hline 3,06 & 2,54 \\
\hline
\end{tabular}

Швидкість повітря $V_{1-4}$ д та баланс витрати

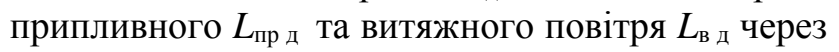
вентиляційних отвори під дією вітру визначаємо відповідно за формулами (4) та (5). Результати розрахунків приведені у табл. 8.
Таблиця 8. Результати розрахунку швидкості повітря та балансу витрати припливного та витяжного повітря через вентиляційних отвори під дісю вітру купольної оранжереї НБС ім. М.М. Гришка.

Table 8. The results calculation of air velocity and flow balance of supply and exhaust air through the ventilation openings under the influence of wind dome greenhouse NBG name's M. M. Grishko.

\begin{tabular}{|c|c|c|c|c|}
\hline$V_{1,2 \mathrm{\mu}, \mathrm{M} / \mathrm{c}}$ & $V_{3,4 \text { д, } \mathrm{M} / \mathrm{c}}$ & $L_{\text {пр д, }} \mathrm{M}^{3} / \mathrm{c}$ & $L_{\mathrm{B} ~}, \mathrm{M}^{3} / \mathrm{c}$ & $L_{\mathrm{cр}}, \mathrm{M}^{3} / \mathrm{c}$ \\
\hline 2,29 & 2,09 & 8,63 & 7,87 & 8,25 \\
\hline
\end{tabular}

Нев'язка по витраті припливного та витяжного повітря під дією вітру складає 9,66 \%.

Одночасній дії гравітаційного тиску та дії вітру визначаємо значення тиску $p_{\text {од }}$ В площині припливних та витяжних вентиляційних отворів при

$$
p_{\text {од }}=p_{\text {гр }}+K p_{\text {д }} \text {. }
$$

Результати розрахунків сумарного значення тиску $p_{1-4}$ од в площині (по центру) припливних та витяжних вентиляційних отворів при одночасній дії гравітаційного тиску та дії вітру приведені у табл. 9.

Таблиця 9. Результати розрахунку сумарного значення тиску в площині припливних та витяжних вентиляційних отворів при одночасній дії гравітаційного тиску та дії вітру

Table 9. The results calculation of the total pressure in the plane of supply and exhaust ventilation openings with the simultaneous influence of the gravitational pressure and wind

\begin{tabular}{|c|c|c|c|}
\hline$p_{1 \text { од, Па }}$ & $p_{2}$ од, Па & $p_{3 \text { од, Па }}$ & $p_{4}$ од, Па \\
\hline 3,50 & 4,00 & 2,98 & 3,48 \\
\hline
\end{tabular}

Швидкість повітря $V_{1-4}$ од та баланс витрати

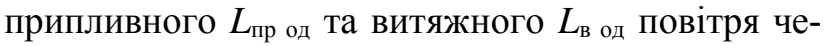
рез вентиляційні отвори при одночасній дії гравітаційного тиску та дії вітру визначаємо відповідно за формулами (4) та (5). Результати розрахунків приведені у табл. 10.

Таблиця 10. Результати розрахунку швидкості повітря та балансу витрати припливного та витяжного повітря через вентиляційних отвори при одночасній дії гравітаційного тиску та дії вітру НБС ім. М.М. Гришка.

Table 10. The results calculation of air velocity and flow balance of supply and exhaust air through the ventilation openings with the simultaneous influence of gravitational pressure and wind NBG name's M. M. Grishko.

\begin{tabular}{|c|c|c|c|c|c|c|}
\hline$V_{1 \text { од, }} / \mathrm{c}$ & $V_{2}$ од, $\mathrm{M} / \mathrm{c}$ & $V_{3 \text { од, }, \mathrm{M} / \mathrm{c}}$ & $V_{4 \text { од }, \mathrm{M} / \mathrm{c}}$ & $L_{\text {пр од, }} \mathrm{M}^{3} / \mathrm{c}$ & $L_{\text {в од, }} \mathrm{M}^{3} / \mathrm{c}$ & $L_{\text {ср од, }} \mathrm{M}^{3} / \mathrm{c}$ \\
\hline 2,45 & 2,64 & 2,26 & 2,46 & 13,48 & 12,65 & 13,07 \\
\hline
\end{tabular}

Нев'язка по витраті припливного та витяжного повітря при одночасній дії гравітаційного тиску та дії вітру складає $6,56 \%$.

Висновки. Проведені натурні та розрахункові дослідження мікрокліматичних параметрів купольної оранжереї "Тропічний ліс" НБС ім. М.М.
Гришка, в процесі яких вимірювалась температура, вологість та швидкість повітря у приміщенні купольній оранжереї, а також у повітрозабірній шахті оранжереї. Проаналізована динаміка зміни температури та швидкості повітря у купольній оранжереї і повітрозабірній шахті впродовж пері- 
оду спостережень. На основі отриманих результатів натурних досліджень розрахована аерація купольної оранжереї для трьох випадків: 1. Під дією гравітаційного тиску; 2. Під дією вітру; 3. При одночасній дії гравітаційного тиску та дії вітру.

В результаті розрахунку аерації купольної оранжереї визначено надлишковий (гравітаційний) тиск та динамічний тиск вітру в площині припливних та витяжних вентиляційних отворів, швидкість повітря через вентиляційні отвори, а також розраховано баланс витрати припливного та витяжного повітря. Визначені площі вентиляційних отворів для забезпечення ефективної аерації приміщення купольної оранжереї. Запропонована схема розміщення припливних та витяжних вентиляційних отворів у купольній оранжереї для організації ефективного повітрообміну і уникнення високих температур повітря (понад $40{ }^{\circ} \mathrm{C}$ ) у літній період.

1. Дроздов В.Ф. Отопление и вентиляция: Учеб. пособие для строит. вузов и фак. по спец. «Теплогазоснабжение и вентиляция» ч. 2. Вентиляция. М. Высш. шк. 1984. 263 с.

2. Тихомиров К.В., Сергеенко Э.С. Теплотехника, теплогазоснабжение и вентиляция. М. Стройиздат. 1991.480 с.

3. Хіменко О.В., Хіменко О.О. Натурні дослідження мікрокліматичних параметрів купольної оранжереї НБС ім M.M. Гришка НАН України. тези доповіді XVIII Міжнародної науково-практичної конференції Відновлювана енергетика та енергоефективність у XXI столітті. Київ. НТУУ КПІ. 2017. C. $654-658$.

4. Михеев М.А., Михеева И.М. Основы теплопередачи. М. Энергия. 1977. 344 с.

5. ДСТУ-Н Б В.1.1-27:2010. Будівельна кліматологія: зі скасуванням СНиП 2.01.01-82, чинний з 01.11. 2011. К. Мінрегіонбуд України. 2011. 127 с.

\section{REFERENCES}

1. Drozdov V.F. Otoplenie i ventilyatsiya. Ucheb. posobie dlya stroit. vuzov i fak. po spets. Teplogazosnabzhenie i ventilyatsiya ch. 2 . Ventilyatsiya. [Heating and ventilation: the study guide for building universities and faculties for specials "Heat and gas supply and ventilation" Part 2. Ventilation]. Moscow. USSR. Vyissh. shk. 1984. 263 p. [in Russian].

2. Tihomirov K.V., Sergeenko E.S. Teplotehnika, teplogazosnabzhenie i ventilyatsiya. [Heat engineering, heat and gas supply and ventilation]. Moscow. USSR. Stroyizdat. 1991. 480 p. [in Russian].

3. Khimenko O.V., Khimenko O.O. Naturni doslidzhennia mikroklimatychnykh parametriv kupol’noyi oranzherei NBS im.
M.M. Hryshka NAN Ukrainy. [Natural research of microclimatic parametrs dome greenhouse NBG name's M. M. Grishko NAS of Ukraine]. The abstracts of the report of the XVIII International Scientific and Practical Conference Renewable energy and energy efficiency in the 21 st century. Kiev. KPI them. Igor Sikorsky. 2017. Pp. 654-658. [in Ukrainian].

4. Miheev M.A., Miheeva I.M. Osnovyi teploperedachi. [Heat transfer basics]. Moscow. USSR. Energiya. 1977. 344 p. [in Russian].

5. DSTU-N B V.1.1-27:2010. Budivelna klimatologiya [Building climatology: with cancel SNiP 2.01.01-82; valid from 01.11. 2011]. Kyiv. Minregionbud of Ukraine. 2011. 127 p. [in Ukrainian].

\section{НАТУРНЫЕ ИССЛЕДОВАНИЯ ПАРАМЕТРОВ МИКРОКЛИМАТА КУПОЛЬНОЙ ОРАНЖЕРЕИ НБС ИМ. Н.Н. ГРИШКО НАН УКРАИНЫ}

\section{А.В. Хименко, канд. техн. наук, Е.А. Хименко}

Институт возобновляемой энергетики НАН Украины, 02094, ул. Гната Хоткевича, 20A, г. Киев, Украина.

Данная работа посвящена комплексному исследованию микроклиматических параметров купольной оранжереи "Тропический лес" НБС им. Н.Н. Гришко с иелью организации эффективной естественной вентиляции (аэрации) оранжереи в тепльй период года. Исследования проводились в несколько этапов. На первом этапе были выполнены измерения температуры и влажности воздуха в купольной оранжереи. На втором этапе были проведены натурные исследования температуры и скорости движения воздуха в воздухозаборной шахте купольной оранжереи в летний период. Получены данные о температуре, влажности, скорости воздуха в купольной оранжереи в течение года, а также в воздухозаборной шахте купольной оранжереи в летний период года. Выполнен анализ полученных данных и динамики изменения этих параметров. Результаты анализа представлены в графической форме. На основе полученных данных натурных исследований была рассчитана аэрация купольной оранжереи НБС им. Н.Н. Гришко для трех случаев: 1. Под действием разности давлений наружсного и внутреннего воздуха; 2. Под действием ветра (ветровая аэрачия); 3. При одновременном действии разницы давлений наружного и внутреннего воздуха и действия ветра. Получены площади приточных и вытяжныых вентиляиионных отверстий, скорость и расход воздуха через них. Предложена схема размещения вентиляиионных отверстий для обеспечения эффективной аэрации помещения купольной оранжереи НБС им. Н.Н. Гришко. Организачия эффективной аэраиии купольной оранжереи позволит создать более благоприятные микроклиматические условия для тропических растений в тепльй период года. Библ. 5, табл. 10, рис. 4.

Ключевые слова: натурные исследования, температура воздуха, влажность, скорость и расход воздуха, вентиляиионные отверстия, аэрация. 